ISSN 0206-5657. Вісник Львівського університету. Серія біологічна. 2020. Випуск 83. С. 67-73 Visnyk of the Lviv University. Series Biology. 2020. Issue 83. P. 67-73

\title{
МІКРОБІОЛОГІЯ
}

UDC: $579 \cdot[22+26+68+81]+546.3$

https://doi.org/10.30970/vlubs.2021.83.08

\section{SYNTHESIS OF GLYCOGEN BY CHLOROBIUM LIMICOLA IMV K-8 WHILE GROWTH IN WASTEWATER}

\author{
T. Segin, S. Hnatush, O. Maslovska, S. Komplikevych
}

\author{
Ivan Franko National University of Lviv \\ 4, Hrushevskyi St., Lviv 79005, Ukraine \\ e-mail:segint@ukr.net
}

\begin{abstract}
Due to the high content of organic compounds, the distillery wastewater can be a good substrate for the production of glycogen during cultivation of green photosynthetic bacteria. Green photosynthetic bacteria Chlorobium limicola IMV K-8 are producers of glycogen and show exoelectrogenic properties when grown alone or inside the co-culture with heterotrophic bacteria-exoelectrogens in wastewater of various origins. In our previous works it was found that due to the phototrophic growth of $C$. limicola IMV K-8 in the distillery wastewater significantly reduces the content of compounds of nitrogen, sulfur, $\mathrm{Ca}^{2+}$, $\mathrm{Mg}^{2+}$ and others. The study of the patterns of glycogen synthesis by green photosynthetic bacteria during growth in such an extreme environment as the wastewater of a distillery has prospects for the development of biotechnology for the production of this polysaccharide. The aim of the study was to investigate the glycogen content in $C$. limicola IMV K-8 cells under different growth conditions in the wastewater of the distillery. Bacteria were grown in the wastewater of the distillery under light (phototrophic growth) and without light exposure (heterotrophic growth). Bacterial cells grown on GSB medium under light (phototrophic growth) and without light (heterotrophic growth) exposure were used as controls. Glycogen content was determined at 7, 14, 21 and 30 days of growth by the glucose oxidase method. Glucose or glycogen in the wastewater of the distillery without the introduction of bacteria was not detected. It was found that the content of glycogen in cells of $C$. limicola IMV K-8 grown in the wastewater of the distillery, under light exposure increased from $3.8 \%$ to $39.8 \%$ of cells dry weight from the seventh to third day of growth during 30 days of cultivation and was 2 times higher the glycogen content of cells on GSB medium. It is assumed that the bacteria $C$. limicola IMV K-8 use available in the water sources of carbon and other compounds necessary for cell metabolism along with glycogen biosynthesis and bioremediation of wastewater. During C. limicola IMV K-8 growth in the darkness there is an assimilation of organic sources of carbon (acetate, pyruvate and probably organic compounds of wastewater), which allows cells to remain viable for 30 days without additional sources of carbon, nitrogen, etc., but significant glycogen synthesis does not occur. The glycogen formed under phototrophic conditions can be further a source of carbon or a substrate for electric current generation by exoelectrogenic bacteria.
\end{abstract}

Keywords: glycogen, wastewater, green photosynthetic bacteria, Chlorobium limicola

Glycogen is one of the reserve nutrients formed by microorganisms. This polysaccharide is a large branched water-soluble homopolymer of $\alpha$-D-glucose residues that are connected by $\alpha-(1 \rightarrow 4)$ - or $\alpha-(1 \rightarrow 6)$-bonds [13,21]. Glycogen plays an important role in the adaptation of bacteria to extreme growth conditions. Its metabolism is coordinated by various systems, in particular, with the participation of regulatory mechanisms of stress response under starvation, the cell's response to osmotic stress, cell redox potential regulation systems, etc. The rpoS, spoT, phoP,

(C) Сегін Т., Гнатуш С., Масловська О., Комплікевич С., 2020 
and $p h o Q$ genes are involved in the regulation of glycogen accumulation in Escherichia coli $\mathrm{K}-12$ [15]. The metabolism of this polysaccharide is associated with the metabolism of sulfur, nitrogen, carbon $[13,22]$. Glycogen is synthesized by many gram-negative, gram-positive bacteria and archaea, in particular, Agrobacterium tumefaciens [21], Rhodococcus sp. [11], Corynebacterium glutamicum [21], Methyloprofundus sedimenti etc. [20, 21]. For some microorganisms, such as Vibrio cholerae, glycogen synthesis is important for survival. It was found that the survival under stress of bacteria $V$. cholerae, which are able to synthesize glycogen, was higher compared to mutants that lost this property $[12,13]$. The accumulation of glycogen in the cells of phototrophic bacteria Chlorobium limicola IMV K-8 under the influence of various factors, in particular the deficiency of nitrogen sources in the environment of GSB, under the influence of different concentrations of hydrogen sulfide or potassium dichromate was studied [7-9].

Phototrophic bacteria have a significant potential to be used at the anode biocatalysts in the microbial fuel cells. These microorganisms under the light exposure provide detoxification of hydrogen sulfide and synthesis of glycogen, which can later be a source of acetate for heterotrophic bacteria-exoelectrogens $[10,16]$. Obtained from Yavorivske lake (Lviv region, Ukraine) green sulfur bacteria $C$. limicola IMV K-8 are producers of glycogen, which is further converted in the processes of energy and constructive metabolism at the darkness $[2,4,9]$. These bacteria are characterized by exoelectrogenic properties during growth on GSB medium and wastewater from a distillery [16]. Wastewater has energy potential due to the high concentration of bioconvertible organic compounds [14]. One of the most polluted industrial wastes is the waste of distilleries, which are characterized by low $\mathrm{pH}$, high temperature, dark brown color, high content of ash elements, dissolved organic and inorganic substances. [17]. In the process of bacteria C. limicola IMV K-8 cultivation in the wastewater of the content of distillery compounds decreased [16]. We assume that due to the high content of organic compounds, the wastewater of the distillery can be a good substrate for the production of glycogen during cultivation of green photosynthetic bacteria. The aim of the study was to investigate the glycogen content in $C$. limicola IMV K-8 cells under different growth conditions in the wastewater of the distillery.

\section{Materials and Methods}

To study the content of glycogen and intracellular glucose under different growth conditions 6-day culture of $C$. limicola IMV K-8 was used. It was grown on Green Sulfur Bacteria (GSB) medium of the following composition (g/l): $\mathrm{KH}_{2} \mathrm{PO}_{4}-0.3 ; \mathrm{NH}_{4} \mathrm{Cl}-0.34 ; \mathrm{KCl}-0.34$; $\mathrm{CaCl}_{2} \times 2 \mathrm{H}_{2} \mathrm{O}-0.15 ; \mathrm{MgSO}_{4} \times 7 \mathrm{H}_{2} \mathrm{O}-0.5$. After autoclaving $15 \mathrm{ml}$ of $10 \% \mathrm{NaHCO}_{3}$ solution, $10 \mathrm{ml}$ of $10 \%$ sodium acetate solution, $10 \mathrm{ml}$ of $10 \%$ sodium pyruvate solution, $2.5 \mathrm{ml}$ of $1 \mathrm{M}$ $\mathrm{Na}_{2} \mathrm{~S} \times 9 \mathrm{H}_{2} \mathrm{O}$ solution, $0.1 \mathrm{ml}$ of vitamin $\mathrm{B}_{12}$ solution $(2 \mathrm{mg} / \mathrm{ml}), 1 \mathrm{ml}$ of micronutrient solution was added $(\mathrm{ml} / \mathrm{l})$. The solution of trace elements per 1 liter of distilled water contained: $25 \%$ $\mathrm{HCl}-10 \mathrm{ml} ; \mathrm{FeSO}_{4} \times 7 \mathrm{H}_{2} \mathrm{O}-2.0 \mathrm{~g} ; \mathrm{CoCl}_{2} \times 6 \mathrm{H}_{2} \mathrm{O}-190 \mathrm{mg} ; \mathrm{MnCl}_{2} \times 4 \mathrm{H}_{2} \mathrm{O}-100 \mathrm{mg} ; \mathrm{ZnCl}_{2}-$ $70 \mathrm{mg} ; \mathrm{Na}_{2} \mathrm{MoO} \times 2 \mathrm{H}_{2} \mathrm{O}-36 \mathrm{mg} ; \mathrm{NiCl}_{2} \times 6 \mathrm{H}_{2} \mathrm{O}-24 \mathrm{mg} ; \mathrm{H}_{3} \mathrm{BO}_{3}-6 \mathrm{mg} ; \mathrm{CuCl}_{2} \times 6 \mathrm{H}_{2} \mathrm{O}-2 \mathrm{mg}$. To prepare a solution of micronutrients the $\mathrm{FeSO}_{4} \times 7 \mathrm{H}_{2} \mathrm{O}$ was dissolved in $\mathrm{HCl}$, the remaining components - in distilled water [3,5]. The optimum $\mathrm{pH}$ was $6.8 \pm 0.2$. The culture was grown under microaerophilic conditions, constant light (wavelength 700-800 nm, intensity - $40 \mathrm{lux}$ ) and at the temperature $28{ }^{\circ} \mathrm{C}[3,5]$. Before cultivation bacteria were precipitated by centrifugation $\left(8000 \mathrm{~g}, 30 \mathrm{~min},+4{ }^{\circ} \mathrm{C}\right.$ ), washed twice with $50 \mathrm{mM}$ Tris- $\mathrm{HCl}$ buffer (pH 7.0) [19]. Initial biomass was $3 \mathrm{~g} / \mathrm{l}$ of bacterial cells. Bacterial biomass was determined turbidimetrically by using a photoelectrocolorimeter $(\lambda=450 \mathrm{~nm}$, optical wavelength $3 \mathrm{~mm})$ [5]. Bacteria were grown in the wastewater of the distillery, which was diluted 10 times with distilled water, under light (phototrophic growth) and without light exposure (heterotrophic growth). Bacterial cells grown on GSB medium under light (phototrophic growth) and without light (heterotrophic growth) exposure 
were used as controls. Glycogen content was determined at 7, 14, 21 and 30 days of growth. Glucose or glycogen in the wastewater of the distillery without the introduction of bacteria was not detected. The content of intracellular glucose and glycogen in the inoculum was $0.1-0.2 \%$ and $0.3-0.5 \%$ of the dry weight of cells, respectively.

To obtain cell-free extracts of bacteria $C$. limicola IMV K-8, they were disintegrated by using an ultrasonic disintegrator USDN-2T $\left(22 \mathrm{kHz}, 5 \mathrm{~min}\right.$ at $\left.0{ }^{\circ} \mathrm{C}\right)$. Remaining cells and cell fragments were separated by centrifugation $\left(8000 \mathrm{~g}, 30 \mathrm{~min}\right.$ at $\left.+4{ }^{\circ} \mathrm{C}\right)$ [19]. The obtained cell-free extract was used to determine the glycogen content. Glycogen hydrolysis was obtained by samples boiling for three hours with $0.5 \mathrm{M} \mathrm{H}_{2} \mathrm{SO}_{4}$. Glucose was accumulated as a result of acid hydrolysis of glycogen in the reaction mixture, which was determined by using the glucose oxidase method with the analytical kit "Diagluk-2", which is highly sensitive and specific to glucose [1].

The main statistical indicators were calculated according to the obtained data (average - M; average standard error $-\mathrm{m}$ ). For evaluation the significance of the difference between the statistical characteristics of the three alternative data sets, the Student's ratio was calculated. The difference was considered significant when the reliability index P>0.95 [6]. MS Excel 2003 and Origin 8 software packages were used for data processing.

\section{Results and Discussion}

Glycogen was synthesized for 30 days during growth of $C$. limicola IMV K-8 bacteria in GSB medium. The content of glycogen in $C$. limicola IMV K-8 cells increased with increasing duration of bacterial cultivation. It was the highest on the 30th day of culture growth and contains $18.2 \%$ of the dry weight of cells, and glucose content $-17.5 \%$ (Fig. 1, A ). Glycogen synthesis occurs during the stationary phase of growth, when the content of nitrogen, sulfur or phosphorus decreases. During this period, bacteria do not grow and protein synthesis is suspended [22].

On the 21th day of bacterial growth in GSB medium, the intracellular glucose content was higher by $15 \%$ in comparison with the glycogen content. We suppose that at this time there are processes of assimilation of available carbon sources and gluconeogenesis, which predominate over the processes of glycogen synthesis. During all other days of cultivation, the content of glycogen in the cells of $C$. limicola IMV K-8 was higher, than the content of glucose (Fig. 1, A). The content of glycogen and glucose in the cells of $C$. limicola IMV K-8, grown in the wastewater of the distillery, under light exposure increased from $3.8 \%$ of dry weight of cells on the seventh day of growth to $39.8 \%$ of dry weight of cells on the 30th day (Fig. 1, B). The glycogen content of bacterial cells grown in the wastewater of the distillery was 2.2 times higher, than the glycogen content during growth in GSB medium. During 30 days of bacterial growth in wastewater, the glycogen content was higher than the intracellular glucose content, which probably indicates the processes of glycogen synthesis. It is known that glycogen synthesis occurs under the influence of stressful conditions on bacterial cells. In case of deficiency of the source of nitrogen, sulfur or phosphorus, the content of glycogen in the cells of Synechocystis sp. was $60-68 \%$ of the dry weight of cells $[13,18]$.

Wastewater from distilleries is characterized by high values of chemical and biological oxygen demand, due to the high content of organic compounds, in particular, polysaccharides, reducing carbohydrates, lignin, proteins, melanoidins, etc. [17]. Since glucose and glycogen were not detected in the investigated wastewater of the distillery before inoculation with $C$. limicola IMV K-8 bacteria, it is assumed that bacteria use available carbon sources for glycogen synthesis.

Under heterotrophic growth conditions, the glycogen content $(0.3-1.7 \%$ of dry cell weight) was lower compared to growth under phototrophic conditions, and increased with prolongation of bacterial growth in GSB medium. Under these conditions, the content of glucose (0.4-2.4\% of dry cell weight) throughout the time of culturing bacteria slightly exceeded the 
content of glycogen (Fig. 2, A). Acetate and pyruvate, which C. limicola IMV K-8 bacteria use as a carbon source, but not as an electron donor, were introduced into the GSB medium. Inoculation material that was used for the experiment was with density of $3 \mathrm{~g} / \mathrm{l}$. Since the bacteria did not increase their biomass during 7-30 days of cultivation, the increase in glucose and glycogen content during 14-30 days was apparently due to the assimilation of acetate and pyruvate in the processes of gluconeogenesis.

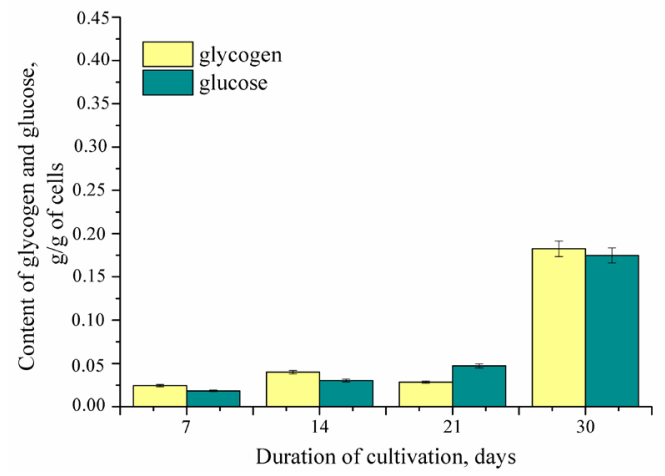

A

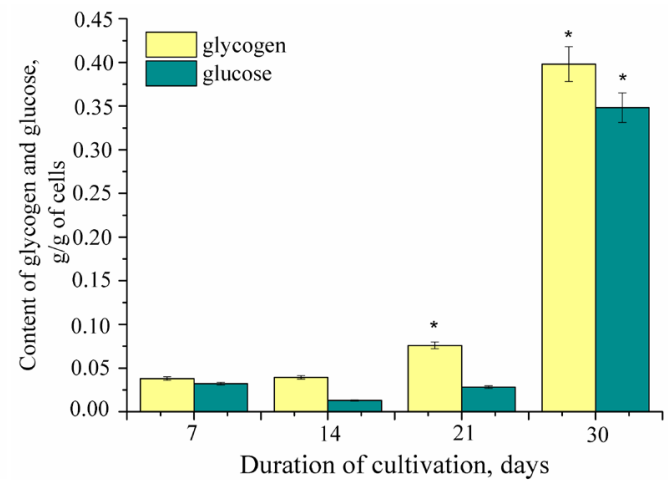

B

Fig. 1. Glycogen and glucose content in cells of Chlorobium limicola IMV K-8 during growth in GSB (A) and in the wastewater of the distillery (B) for 30 days under light exposure $(*-p \geq 0,95, n=3-$ probable changes in comparison with control)

During the heterotrophic growth of $C$. limicola IMV K-8 in the wastewater of the distillery, glycogen content did not exceed $0.2 \%$ of the dry weight of the cells. The highest content of this polysaccharide was found during seventh day of culture growth. With the further increase in the duration of bacterial growth, the glycogen content was insignificant (Fig. 2, B). It is assumed that the content of glycogen in the cells of $C$. limicola IMV K-8 during 7 days of cultivation is a polysaccharide residue in the inoculation material, which during long-term cultivation in the darkness is broken down into glucose. The intracellular glucose content was lower compared to the growth in wastewater under light exposure, but significantly exceeded the glycogen content in bacterial cells under these conditions. It is assumed that bacteria metabolize organic compounds present in wastewater, as a result of which the glucose content increases.

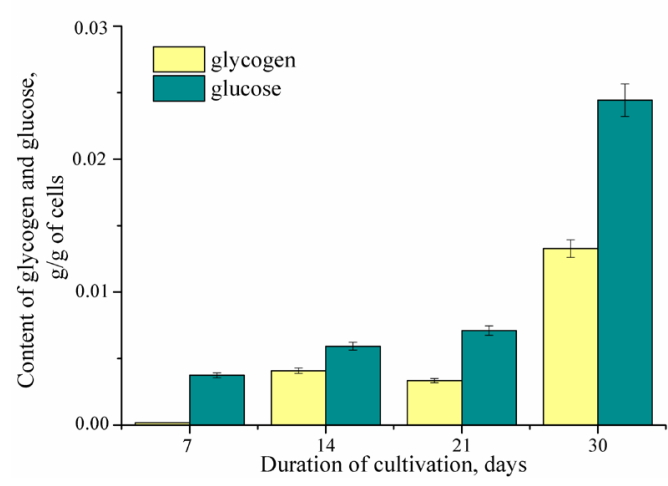

A

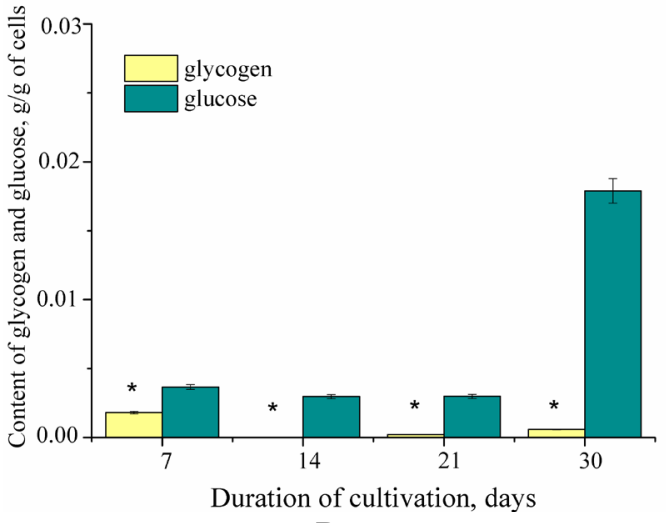

B

Fig. 2. Glycogen and glucose content in cells Chlorobium limicola IMV K-8 during growth in GSB (A) and in the wastewater of the distillery (B) during 30 days without light exposure $\left(^{*}-\mathrm{p} \geq 0,95, \mathrm{n}=3-\right.$ probable changes compared to control) 
Thus, during the growth in the darkness $C$. limicola IMV K-8 assimilates organic sources of carbon (acetate, pyruvate and probably organic compounds of wastewater), which allows cells to remain viable for 30 days without adding of additional sources of carbon, nitrogen, etc. but significant glycogen synthesis does not occur.

In our previous work [16] it was found that during growth under the light and darkness exposure, as well as during long-term growth in the anode chamber of microbial fuel cell $\mathrm{C}$. limicola IMV K-8 oxidizes organic compounds, as evidenced by the increase of pair $\mathrm{HCO}_{3}{ }^{-} / \mathrm{CO}_{3}{ }^{2-}$. We assume that at excess of organic matter in wastewater, the processes of organic matter catabolism by glycolysis or pentose phosphate pathway enzymes predominate in C. limicola IMV K-8 cells, and as a result $\mathrm{CO}_{3}{ }^{2-}$ is formed. However, the content of $\mathrm{H}_{2} \mathrm{~S}$, which is one of the main electron donors for these bacteria in the process of photosynthesis, is also significantly reduced. It is obvious that under these conditions the processes of photosynthesis can occur, however, with reduced intensity. During bacteria growth in the wastewater of the distillery the content of sulfate, sulfide ions and elemental sulfur, which can be substrates of assimilative sulfur reduction, and nitrate and nitrite ions also decreases. $\mathrm{NH}_{4}^{+}$is known to be a source of nitrogen for C. limicola IMV K-8, so it is likely that a decrease in the content of these ions may be due to their assimilation. [16].

Therefore, green photosynthetic bacteria synthesize glycogen during growth in the wastewater of the distillery, providing bioremediation of the water. The glycogen formed under phototrophic conditions can be further a source of carbon or a substrate for generation of an electric current by exoelectrogenic bacteria.

\section{REFERENCES}

1. Gonchar M. V. Sensitive method for quantitative determination of hydrogen peroxide and oxidase substrates in biological objects // Ukrainian Biochemical Journal. 1998. Vol. 70. № 5. P. 157-163.

2. Gorishniy M., Gudz S., Hnatush S. Metabolism of glucose and glycogen in the cells of green photosynthetic sulfur bacteria Chlorobium limicola Ya-2002 // Visnyk of the Lviv University. Series Biology. 2008. Vol. 46. P. 129-136.

3. Gorishny M., Gudz S., Hnatush S. Bacterial photosynthesis. Lviv: Ivan Franko National University of Lviv, 2011. 179 p.

4. Gorishniy M., Hnatush S., S. Gudz S. Carbon dioxide metabolism in the cells of green bacteria // Visnyk of the Lviv University. 2012. Vol. 59. P. 12-22.

5. Gudz S.P., Hnatush S.O., Yavorska G.V. et.al. Workshop on microbiology: a textbook. Lviv: Ivan Franko National University of Lviv, 2014. 436 p.

6. Lakin G.F. Biometrics. M.: Highter school, 1990. 352 p.

7. Moroz O., Hnatush S., Bohoslavets C. et al. Potassium dichromate influence on some physiolocal peculiarities of sulfur cycle bacteria from Yavorivske lake // Visnyk of the Lviv University. Series Biology. 2017. Vol. 75. P. 127-139.

8. Moroz O., Pakush C., Zvir G. et al. Growth, hydrogen sulfide utilization and endogenous carbohydrates accumulation by photolithotrophic sulfur bacteria upon the influence of metal ions // Visnyk of the Lviv University. Series Biology. 2015. Vol. 69. P. 227-240.

9. Pat. 63723 Ukraine, IPC (2011) C12N 1/20 (2006.01), C08B 37/18 (2006.01). Consortium of bacteria Chlorobium limicola Ya-2002 and Pseudomonas sp. - glycogen producer / Horishny M. B., Hnatush S. O., Moroz O. M., Levitska O. V., Gudz S. P.; applicant and owner Ivan Franko National University of Lviv. № u201014885; Application 13.12.2010; Publ. 25.10.2011, Bull. № 20, 2011. 
10. Badalamenti J. Coupling dark metabolism to electricity generation using photosynthetic cocultures // Biotechnology and Bioengineering. 2014. Vol. 111. № 2. P. 223-231. https://doi. org/10.1002/bit.25011

11. Bequer Urbano S., Albarracin V. H., Ordonez O. F. et al. Lipid storage in high-altitude Andean Lakes extremophiles and its mobilization under stress conditions in Rhodococcus sp. A5, a UV-resistant actinobacterium // Extremophiles. 2013. Vol. 17. P. 217-227. https://doi. org/10.1007/s0079 2-012-0508-2

12. Bourassa L., Camilli A. Glycogen contributes to the environmental persistence and transmission of Vibrio cholerae // Mol. Microbiol. 2009. Vol. 72. P. 124-138. https://doi.org/10.1111/ j.1365-2958.2009.06629.x

13. Cifuente J., Comino N., Trastoy B. et al. Structural basis of glycogen metabolism in bacteria // Biochemical Journal. 2019. Vol. 476. № 14. P. 2059-2092. https://doi.org/1 0.1042/ BCJ20170558

14. Do M., Ngo H., Guo W. et al. Challenges in the application of microbial fuel cells to wastewater treatment and energy production: a mini review // Science of the Total Environment. 2018. Vol. 639. P. 910-920. https://doi.org/10.1016/j.scitotenv.2018.05.136

15. Eydallin G., Montero M., Almagro G. et al. Genome-wide screening of genes whose enhanced expression affects glycogen accumulation in Escherichia coli // DNA research. 2010. Vol. 17. № 2. P. 61-71. https://doi.org/10.1093/dnares/dsp028

16. Hnatush S. O., Maslovska O. D., Segin T. B. et al. Waste water treatment by exoelectrogenic bacteria, which were isolated from technogenically transformed territories // Ecological Question. 2020. Vol. 31. № 1. C. 35-44. http://dx.doi.org/10.12775/EQ.2020.005

17. Kharayat $Y$. Distillery wastewater: bioremediation approaches // Journal of Integrative Environmental Sciences. 2012. Vol. 9. № 2. P. 69-91.

18. Rueda E., Garcia-Galán M. J., Diez-Montero R. et al. Polyhydroxybutyrate and glycogen production in photobioreactors inoculated with wastewater borne cyanobacteria monocultures // Bioresource technology. 2020. Vol. 295. P. 122233. https://doi: 10.1016/j.biortech.2019.122233

19. Segin T. B., Hnatush S. O, Maslovska O. D. et al. Biochemical indicators of green photosynthetic bacteria Chlorobium limicola response to $\mathrm{Cu}^{2+}$ action // The Ukrainian Biochemical Journal. 2020. Vol. 92. № 1. C. 103-112. https://doi.org/10.15407/ubj92.01.1

20. Tavormina P. L., Kellermann M. Y., Antony C. P. et al. Starvation and recovery in the deep-sea methanotroph Methyloprofundus sedimenti // Molecular Microbiology. 2017. Vol. 103. № 2. P. 242-252. https://doi.org/10.1111/mmi.13553

21. Wang L., Wang M., Wise M. J. et al. Recent progress in the structure of glycogen serving as a durable energy reserve in bacteria // World Journal of Microbiology and Biotechnology. 2020. Vol. 36. № 1. P. 1-12. https ://doi: 10.1007/s11274-019-2795-6.

22. Wilson W. A., Roach P. J., Montero et al. Regulation of glycogen metabolism in yeast and bacteria // FEMS microbiology reviews. 2010. Vol. 34. № 6. P. 952-985. https://10.1111/ j.1574-6976.2010.00220.x 
T. Сегін, С. Гнатуш, О. Масловська, С. Комплікевич

\title{
СИНТЕЗ ГЛІКОГЕНУ CHLOROВIUM LIMICOLA IMB К-8 ЗА РОСТУ НА СТІЧНІЙ ВОДІ
}

\author{
Т. Сегін, С. Гнатуш, О. Масловська, С. Комплікевич
}

\author{
Львівський національний університет імені Івана Франка \\ вул. Грушевського, 4, Львів 79005, Украӥна \\ e-mail:segint@ukr.net
}

\begin{abstract}
Унаслідок високого вмісту органічних сполук стічні води спиртового заводу можуть бути хорошим субстратом для отримання глікогену за вирощування на них зелених фотосинтезувальних бактерій. Зелені фотосинтезувальні бактерії Chlorobium limicola IMB К-8 є продуцентами глікогену і виявляють екзоелектрогенні властивості за росту окремо або в ко-культурі з гетеротрофними бактеріями-екзоелектрогенами на стічних водах різного походження. У наших попередніх роботах встановлено, що внаслідок фототрофного росту C. limicola IMB К-8 у стічній воді спиртового заводу значно знижується вміст сполук Нітрогену, Сульфуру, $\mathrm{Ca}^{2+}, \mathrm{Mg}^{2+}$ тощо. Дослідження закономірностей синтезу глікогену зеленими фотосинтезувальними бактеріями за росту в такому екстремальному середовищі як стічні води спиртового заводу має перспективу для розроблення біотехнології отримання цього полісахариду. Метою роботи було дослідити вміст глікогену в клітинах C. limicola IMB K-8 за різних умов росту на стічній воді спиртового заводу. Бактерії вирощували на стічній воді спиртового заводу за умов освітлення (фототрофний ріст) і без освітлення (гетеротрофний ріст). Як контроль використовували клітини бактерій, вирощених на середовищі GSB за освітлення (фототрофний ріст) і без освітлення (гетеротрофний ріст). Вміст глікогену визначали на 7, 14, 21 і 30-ту доби росту 3 використанням глюкозооксидазного методу. Глюкози або глікогену у стічній воді спиртового заводу без внесення бактерій не було виявлено. Встановлено, що вміст глікогену в клітинах C. limicola IMB К-8, вирощених на стічній воді спиртового заводу, за умови освітлення зростав від 3,8 \% сухої маси клітин на 7-му добу росту до 39,8 \% сухої маси клітин упродовж 30-ї доби росту культури і удвічі перевищував вміст глікогену в клітинах за росту на середовищі GSB. Припускаємо, що бактерії C. limicola IMB К-8 використовують наявні у воді джерела Карбону й інші необхідні для метаболізму клітини сполуки, що супроводжується біосинтезом глікогену та біоремедіацією стічної води. За росту C. limicola IMB К-8 у темряві відбувається асиміляція органічних джерел Карбону (ацетату, пірувату i, ймовірно, органічних сполук стічної води), що дає змогу клітинам зберігати життєдіяльність упродовж 30 діб без внесення додаткового джерела Карбону, Нітрогену тощо, але значного синтезу глікогену не відбувається. Утворений за фототрофних умов глікоген у подальшому може бути субстратом для генерації електричного струму екзоелектрогенними бактеріями або після гідролізу - джерелом Карбону.
\end{abstract}

Ключові слова: глікоген, стічні води, зелені фотосинтезувальні бактерії, Chlorobium limicola 